\title{
Hydrolysis of Egg Yolk Protein in a Packed Bed Reactor by Immobilized Enzyme
}

\author{
Byung Chul Kang*
}

\section{Department of Chemical Engineering, Dong-Eui University, Busan 614-714, Korea}

Received August 18, 2010 /Accepted November 11, 2010

\begin{abstract}
Alkaline protease for the hydrolysis of egg yolk protein was immobilized on five carriers - Duolite A568, Celite R640, Dowex-1, Dowex 50W and Silica gel R60. Duolite A568 showed a maximum immobilization yield of $24.7 \%$. Optimum $\mathrm{pH}$ for the free and immobilized enzyme was $\mathrm{pH} 8$ and 9, respectively. However, no change was observed in optimum temperature $\left(50^{\circ} \mathrm{C}\right)$. Thermal stability was observed in immobilized enzymes compared to free enzymes. The immobilized enzyme retained $86 \%$ activity after 10 cycle operations in a repeated batch process. The effect of flow rate on the stability of enzyme activity in continuous packed-bed reactor was investigated. Lowering flow rate increased the stability of the immobilized enzyme. After $96 \mathrm{hr}$ of continuous operation in a packed-bed reactor, the immobilized enzyme retained 83 and $61 \%$ activity when casein and egg yolk were used as a raw materials, respectively.
\end{abstract}

Key words : Enzyme immobilization, egg yolk protein, packed-bed reactor, continuous operation, repeated batch

\section{서 론}

식품가공 산업에 널리 사용되고 있는 계란은 난백이 주로 사용되고 있고 난황을 가공하는 수요는 적은 실정이다. 난황 은 수분을 제외하고 지질과 단백질로 구성되어 있다[11]. 난 황 단백질의 가수분해에 의해 추출된 시알산올리고당 (sialyloligosaccharide)은 항 염증 작용, 바이러스 감염의 예방 및 학습기능의 향상시키는 작용이 있어 의약품 및 기능성 식 품의 소재로 연구되고 있다[8,16]. 효소를 이용한 난황 단백질 가수분해 공정은 회분식으로 인해 생산성의 감소와 효소를 재사용할 수 없는 단점이 있다. 회분식 공정의 단점을 극복하 기 위한 효소 고정화에 의한 연속공정은 개발되어있지 않은 상태이다.

고정화 효소를 이용한 식품, 제약 그리고 생명 분야의 제품 생산에 대한 많은 연구가 진행되어 왔다[5]. Alkaline protease 를 담체에 고정화 시키는 방법도 일반적인 효소의 경우와 같 은데 고정화 효소는 불용성 물질에 효소를 흡착하는 방법 $[3,23]$, 젤 상태의 물질에 효소를 가두는 방법 $[9,17,21]$, 고분자 의 상태에 따라 sol/gel상태로 고정화 방법[21,22], 이중의 작 용기를 갖는 시약에 상호 가교하는 방법[2], 그리고 불용성 담 체에 효소를 공유 결합 하는 방법 $[10,15,18]$ 등이 있다. 일반적 으로 상업적인 반응기는 용해 효소를 직접 사용하여 혼합 반 응기에서 회분식으로 운전되는 것으로 알려져 있다. 하지만 생산성이 낮은 회분식 공정보다 생산성 및 운전 안정성을 향 상시키기 위한 고정화 효소를 이용한 연속식 공정의 개발이

*Corresponding author Tel : +82-51-890-1702, Fax : +82-51-890-1694 E-mail : bckang@deu.ac.kr
널리 진행되어 왔다 $[4,6,13]$. 고정화 효소를 이용한 연속식 공 정은 제품의 회수를 용이하게 하여 분리 정제비용을 감소시킬 수 있고, 고정화에 의해 효소 촉매가 반응하는 좋은 환경을 제공할 수 있고, 그리고 효소를 계속적으로 재사용할 수 있는 여러 가지 장점이 있다. 유기물 또는 무기물 담체를 이용하여 단백질 가수분해 효소의 고정화에 대한 연구가 진행되었지만 다른 효소에 비해 많은 연구가 진행되지는 않았다.

본 연구는 난황 단백질의 가수분해를 위한 연속공정을 개발 하기 위해 효소를 여러 가지 담체에 고정화하여 그 특성을 조사하여 최적의 담체를 선별하고자 하였다. 고정화 효소에 대한 최적의 조건을 위한 $\mathrm{pH}$, 온도, 그리고 열 안정성을 평가 하였다. 충진층 반응기를 사용하여 연속식 운전을 실시하여 공정 변수들에 대한 적절한 조업조건을 평가하고 연속운전에 서 장시간 조업을 통한 고정화 효소의 안정성을 평가하였다.

\section{재료 및 방법}

\section{효소 및 시약}

단백질 가수분해 효소는 alkaline protease인 Orientase BF-22 (EC 3.4.21.62; Hankyu Bio-industry, Osaka, Japan)를 사용하였다. 효소 고정화를 위해 5 가지의 담체는 무기 담체인 Celite R640과 Silica gel 60은 Fluka에서 구입하였고, 이온교환 수지로 사용되는 유기 담체인 Duolite A568는 Rohm and Haas에서, 그리고 Dowex W50과 Dowex 1은 Sigma에서 구입 하여 사용하였다. 난황 단백질은 난황 분말을 에탄올로 추출 하여 사용하였고 효소 가수분해 전에 $90^{\circ} \mathrm{C}$ 에서 열처리하였다. 다른 모든 시약은 특급 이상을 사용하였다. 


\section{효소 고정화}

Duolite A568에 효소 고정화 방법은 담체의 활성화와 효소 고정화 두 단계로 실시되었다. 담체 활성화 방법은 다음과 같 다. Duolite A568 $1.0 \mathrm{~g}$ 에 증류수 $10 \mathrm{ml}$ 로 10분간 교반 세척한 다음 원심 분리하였고 여기에 $1 \mathrm{M} \mathrm{HCl} 5 \mathrm{ml}$ 를 투입한 후 증류 수 세척과 같은 방법으로 실시하였고 그 다음에 $1 \mathrm{M} \mathrm{NaOH}$ $5 \mathrm{ml}$ 를 투입한 후 10 분간 교반 세척 후 원심 분리하였다. 마지 막으로 증류수 $10 \mathrm{ml}$ 를 넣고 세척한 후 $0.1 \mathrm{M}$ Tris- $\mathrm{HCl}$ 완충 용액(pH 9.0) $10 \mathrm{ml}$ 으로 2회에 걸쳐 담체를 세척하였다. 이와 같이 활성화된 담체에 효소를 고정화하였는데 Duolite A568 $1.0 \mathrm{~g}$ 을 $8.0 \mathrm{mg} / \mathrm{ml}$ 효소용액 $20 \mathrm{ml}$ 에 첨가하고 $4^{\circ} \mathrm{C}$ 에서 24 시 간 동안 교반 하면서 고정화하였다. 고정화된 효소를 완충용 액으로 세척하였다. Silica gel 60과 Celite R640의 효소고정화 는 각각 담체 $1.0 \mathrm{~g}$ 을 $0.1 \mathrm{M}$ Tris- $\mathrm{HCl}$ 완충 용액 $(\mathrm{pH}$ 9.0)으로 제조된 $8.0 \mathrm{mg} / \mathrm{ml}$ 효소용액 $20 \mathrm{ml}$ 에 첨가하고 $4^{\circ} \mathrm{C}$ 에서 24 시간 동안 교반 하면서 고정화하였다. 고정화된 효소를 완충 용액을 사용하여 세척하였다. Dowex에 효소를 고정화하기 위 해서는 우선 담체 $1 \mathrm{~g}$ 을 완충용액 $25 \mathrm{ml}$ 에 첨가하고 상온에서 24시간 교반 하면서 담체가 완충용액에 평형이 되도록 하였 다. 담체를 회수하여 $8.0 \mathrm{mg} / \mathrm{ml}$ 효소용액 $20 \mathrm{ml}$ 에 첨가하고 $4^{\circ} \mathrm{C}$ 에서 24 시간 동안 교반 하면서 고정화하였다.

\section{효소 활성 측정}

단백질 분해 효소 활성은 다음과 같이 측정하였다. Tris- $\mathrm{HCl}$ buffer $(0.1 \mathrm{M}, \mathrm{pH}$ 9.0)에서 제조된 $1.5 \%$ (w/v)의 수용성 casein $2 \mathrm{ml}$ 에 자유효소의 활성을 측정하는 경우에는 $8.0 \mathrm{mg} / \mathrm{ml}$ 효소용액 $1 \mathrm{ml}$ 혹은 고정화 효소 활성 측정인 경우 에는 무게가 측정된 고정화 효소를 넣고 반응 용액으로 하였 다. 반응용액을 $37^{\circ} \mathrm{C}$ 에 항온조에서 10 분간 반응한 후, $15 \%$ (w/v) Trichloroacetic acid $2 \mathrm{ml}$ 를 넣고 반응을 중지시켰다. $0.5 \mathrm{M}$ 의 $\mathrm{Na}_{2} \mathrm{CO}_{3}$ 용액 $5 \mathrm{ml}$ 에 증류수 $1 \mathrm{ml}$ 와 Folin 시약 $1 \mathrm{ml}$ 를 넣고 원심분리 후 얻어진 상등액과 혼합하여 $37^{\circ} \mathrm{C}$ 에서 30 분 동안 반응하여 발색시켰다. $660 \mathrm{~nm}$ 에서 tyrosine을 표준으로 흡광도를 측정하여 효소 활성을 결정하였다[7]. 효소 활성 1 unit는 분당 tyrosine $1 \mu \mathrm{mol}$ 을 생성시키는 효소의 양으로 정의 한다. 자유 효소와 고정화 효소의 단백질 양은 Lowry 방법으로 Bovine serum albumin을 표준으로 하여 측정하였다[12].

\section{최적의 $\mathrm{pH}$ 와 온도}

자유 효소와 고정화 효소 활성에 대한 최적의 $\mathrm{pH}$ 와 온도를 다음과 같이 조사하였다. $\mathrm{pH}$ 는 $50^{\circ} \mathrm{C}$ 에서 $0.1 \mathrm{M} \mathrm{NaOH}$ 나 $\mathrm{HCl}$ 로 조절하면서 6 에서 11 까지 변화시켰다. 온도는 $\mathrm{pH}$ 9에서 $35^{\circ} \mathrm{C}$ 부터 $65^{\circ} \mathrm{C}$ 까지 변화시켰다.

\section{$\mathrm{pH}$ 안정성}

자유 효소와 고정화 효소를 $\mathrm{pH}$ 6에서 11의 조건에서 2시간
동안 반응 시킨 후 효소 활성을 측정하였다.

\section{열 안정성}

자유 효소와 고정화 효소의 열 안정성은 Tris- $\mathrm{HCl}$ buffer $(0.1 \mathrm{M}, \mathrm{pH}$ 9.0)에서 온도를 달리하면서 30 분간 반응시킨 후 남아있는 효소활성을 측정하고 이것을 원래의 효소 활성에 대한 비율로서 표시하였다.

\section{재사용 회분식(repeated batch) 조업}

고정화 효소의 재사용 성능을 평가하기 위해 고정화 효소 를 2시간 동안 casein의 가수분해를 실시한 후 고정화 효소를 증류수로 1회 그리고 Tris- $\mathrm{HCl}$ buffer (0.1 M, pH 9.0)로 2회 세척한 후 다시 반응을 실시하였다. 각 반응 단계에서 고정화 효소의 활성을 측정하였다.

\section{충진층(packed-bed) 반응기 조업}

충진층 반응기의 길이는 $20 \mathrm{~cm}$, 내부지름은 $2.8 \mathrm{~cm}$ 이고 $\mathrm{sin}-$ tered glass filter와 water jacket을 부착하여 온도조절이 가능 하게 하였다. 충진층 반응기에 고정화 효소를 투입하고 난황 단백질 용액을 부피유속을 달리하면서 공급하였다. 연속공정 에서는 원료인 난황단백질 용액의 오염을 방지하기 위해 $4^{\circ} \mathrm{C}$ 항온조에서 용액을 유지하였다. 고정화된 효소 $30 \mathrm{~g}$ 을 충진층 반응기에 투입한 후 peristaltic 펌프(Eyela MP-3, Japan)로 원 료 난황단백질 용액을 반응기에 공급하였다. 충진층 반응기를 이용한 연속공정의 개괄도가 Fig. 1에 나타내었다. 연속 공정 에서는 5시간의 간격마다 시료채취를 하였으며 96 시간 동안 운전하면서 효소의 활성을 측정하였다. 부피유속을 30 에서 $110 \mathrm{ml} / \mathrm{hr}$ 로 변화시키면서 고정화된 효소의 활성 및 운전 성

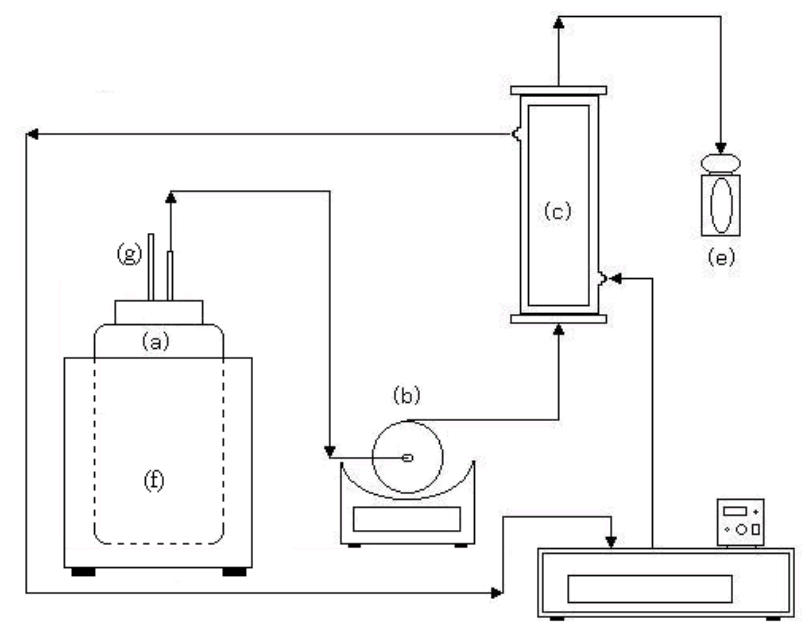

(d)

Fig. 1. Schematic Diagram of packed-bed reactor system. (a) feed reservoir, (b) peristaltic pump, (c) packed column enzyme reactor, (d) water bath, (e) cryogenic vial (sampling bottle), (f) cooler, (g) air filter. 
Table 1. Immobilization yield of alkaline protease on different carriers by adsorption

\begin{tabular}{lcccc}
\hline Carriers & $\begin{array}{c}\text { Added enzyme } \\
\text { (U/g carrier) }\end{array}$ & $\begin{array}{c}\text { Unbound enzyme } \\
\text { (U/g carrier) }\end{array}$ & $\begin{array}{c}\text { Bound enzyme } \\
\text { (U/g carrier) }\end{array}$ & $\begin{array}{c}\text { Immobilization yield } \\
(\%)\end{array}$ \\
\hline Silica gel 60 & 1000 & 760.2 & 44.4 & 18.5 \\
Celite R640 & 1000 & 730.9 & 56.5 & 21.0 \\
Duolite A568 & 1000 & 803.9 & 48.4 & 24.7 \\
Dowex 1 & 1000 & 823.2 & 8.1 & 4.6 \\
Dowex W50 & 1000 & 830.2 & 15.3 & 9.0 \\
\hline
\end{tabular}

능을 평가하였다. 또한 난황 단백질을 원료로 사용하였을 때 casein과 연속 조업의 특성을 비교하였다.

\section{결과 및 고찰}

\section{효소 고정화 효율}

사용된 5 가지 담체에 대한 효소의 고정화 효율을 비교하였 다(Table 1). 고정화 효율은 고정화 효소활성에 대한 투입된 효소활성과 여액으로 나가는 효소활성의 차를 나누어 주어 그것의 백분율로 결정하였다. 이온교환수지인 Duolite A568 에 대한 고정화 효율이 $24.7 \%$ 로 가장 높았다. 따라서 본 실험 에서는 Duolite A568을 고정화 담체로 선정하여 실험하였다. 무기담체인 Silica gel 60과 Celite R640에서도 효소 고정화 효 율이 Dowex에 비해 높음을 알 수 있다.

자유 효소와 고정화 효소의 최적 $\mathrm{pH}$ 비교

$\mathrm{pH}$ 변화에 자유효소와 Duolite 담체에 고정화된 효소의 활 성을 비교하였다(Fig. 2). 자유효소의 경우는 $\mathrm{pH} 8$ 에서 최대 활성을 보였고 고정화 효소는 $\mathrm{pH}$ 9에서 최대 활성을 보였다. 고정화 효소의 최적 $\mathrm{pH}$ 가 자유효소와 달리 변화하는 이유는

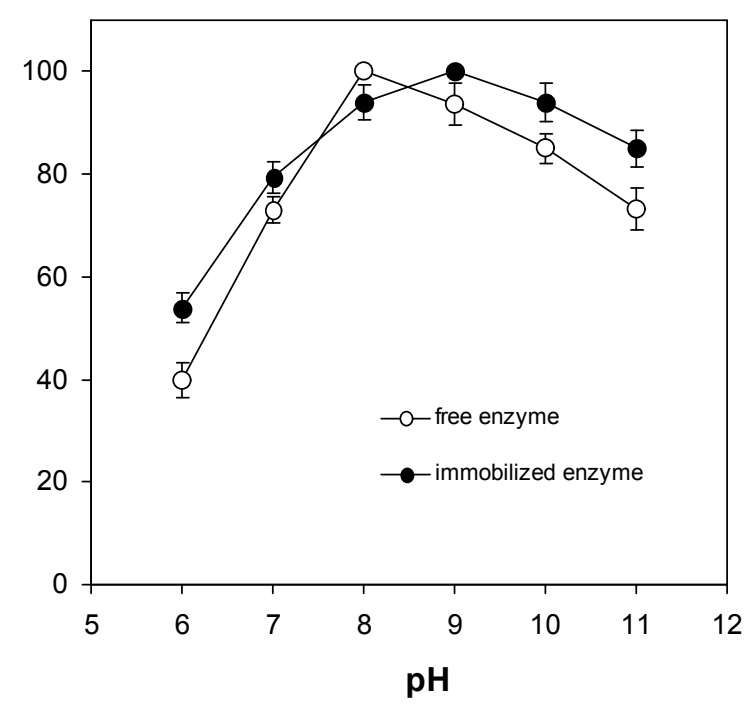

Fig. 2. Effect of $\mathrm{pH}$ on the relative activity of the free and immobilized enzyme.
담체에 효소가 고정화에 의해 효소의 미세 환경이 변화하기 때문이다[19]. 일반적으로 고정화 효소는 담체와 효소의 전하 적인 결합에 의해 수소이온의 변화가 유발된다고 설명된다. 전체적인 $\mathrm{pH}$ 범위에서 자유효소에 비해 고정화 효소의 활성 이 보다 넓게 분포됨을 알 수 있다. 이것은 고정화 효소의 활성 이 $\mathrm{pH}$ 변화에 대해 덜 민감하게 작용하고 있음을 알 수 있다.

\section{$\mathrm{pH}$ 에 대한 안정성}

$\mathrm{pH}$ 에 대한 안정성을 평가하기 위해 각각 $\mathrm{pH}$ 에서 2시간 동안 반응한 후 효소 활성을 측정하였다(Fig. 3). 고정화 효소 가 각 $\mathrm{pH}$ 에서 자유효소에 비해 안정성이 높음을 알 수 있다. 이것은 조업 조건에서 고정화 효소가 외부의 $\mathrm{pH}$ 에 변화에 대 해 덜 민감하게 작용하여 조업에 유리할 수 있다는 것을 제시 한다.

\section{자유 효소와 고정화 효소의 최적 온도 비교}

온도 변화에 따른 자유효소와 고정화 효소의 활성을 비교하 였다(Fig. 4). 온도가 증가할수록 자유 효소와 고정화 효소의 활성은 같은 경향으로 증가하였고, 두 경우 모두 $50^{\circ} \mathrm{C}$ 에서 최 대 활성을 보였다. $50^{\circ} \mathrm{C}$ 이상으로 증가시킬 때 효소활성은 감 소하였는데 자유효소의 활성이 고정화 효소에 비해 훨씬 더

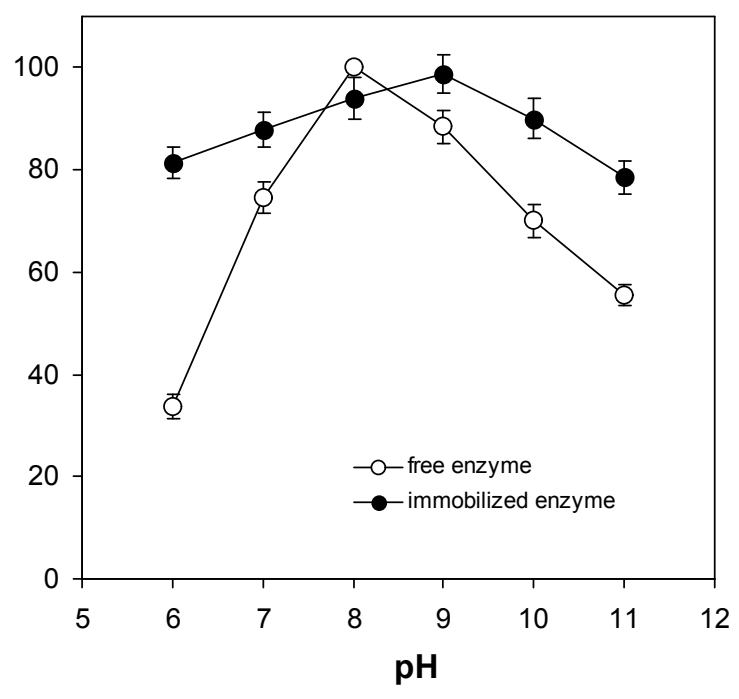

Fig. 3. $\mathrm{pH}$ stability of the free and immobilized enzyme. 


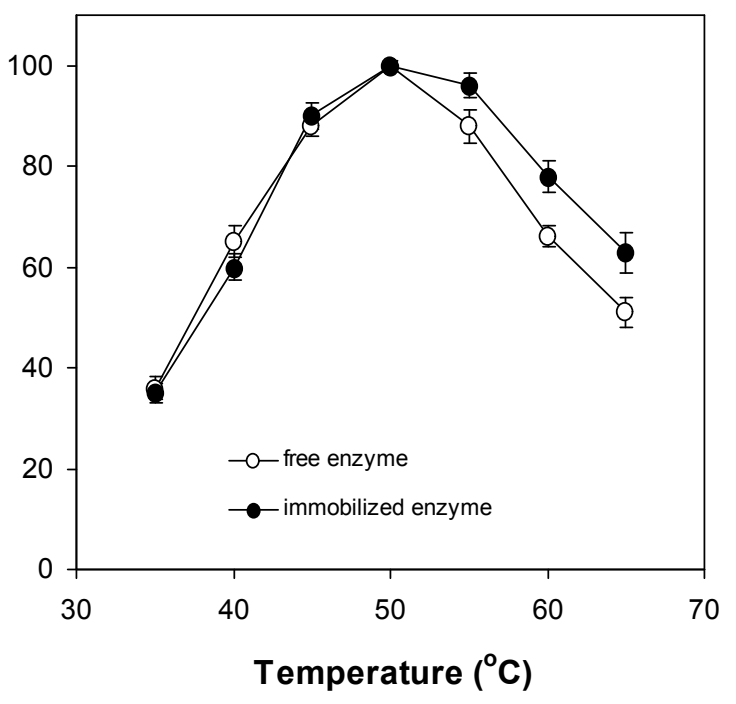

Fig. 4. Effect of temperature on the relative activity of the free and immobilized protease.

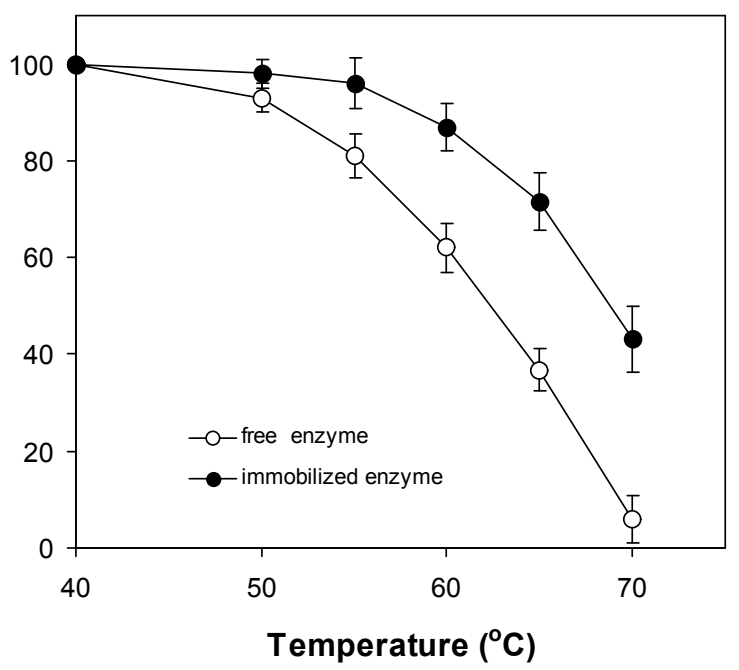

Fig. 5. Thermal stability of the free and immobilized enzyme.

빨리 감소하는 것을 알 수 있다. 이것은 고정화 효소가 온도에 도 덜 민감하게 작용하는데 이것은 고정화에 의해 열에 대한 안정성이 증가하였음을 나타낸다.

\section{열 안정성}

각각의 온도에서 30 분 동안 효소반응을 진행한 후 자유 효 소와 고정화 효소의 활성을 측정하여 열 안정성을 평가하였다 (Fig. 5). 고정화 효소가 자유 효소에 비해 높은 열 안정성을 나타냄을 알 수 있다. 이 결과는 담체와 효소의 이온결합에 의해 안정화되기 때문인데 자유 효소에 비해 고정화 효소 공 정을 채택하는 이유이기도 하다[5].

\section{재사용 회분식 운전}

고정화 효소의 반복적인 재사용은 실제 공정의 응용에서

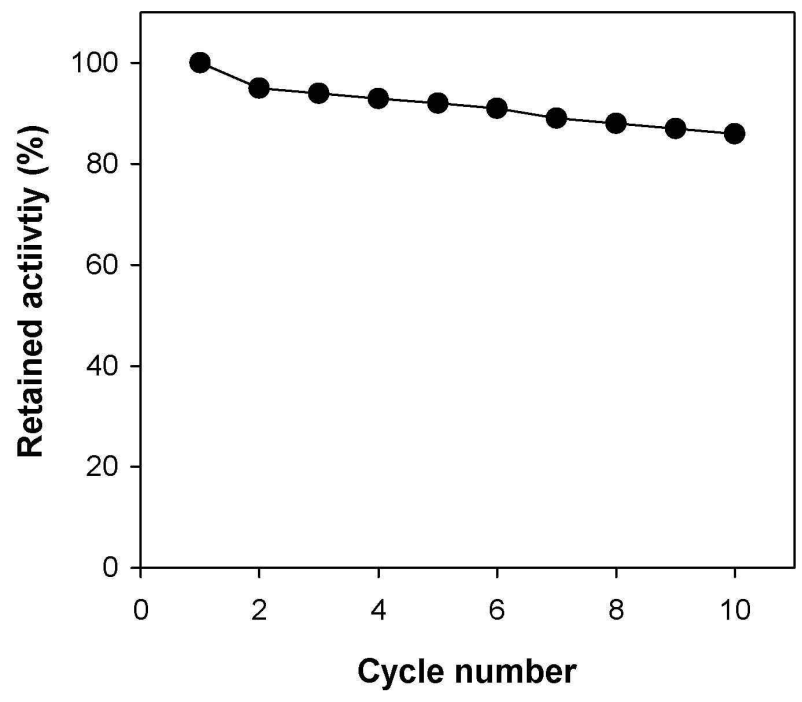

Fig. 6. Retained activity of the immobilized alkaline protease after cycles of repeated batch operation (initial activity was taken as $100 \%$ ).

중요하다. 고정화 효소를 회분식 효소반응으로 2시간 반응을 시킨 후 고정화 효소를 세척하고 다시 효소반응을 반복적으로 실시하여 10 cycle 동안 효소 안정성을 측정하였다(Fig. 6). 10 cycle 후에 고정화 효소는 초기 활성의 $86 \%$ 를 유지하였다. 이 결과는 재사용 회분식 운전에서 고정화 효소가 안정적으로 효소활성을 유지하는 것을 보여준다. 일반적 경우 공유결합에 의한 고정화 효소의 활성이 물리적인 이온결합의 활성보다 높다고 보고되어 있지만, 이온결합에 의한 고정화 효소는 연 속 조업에서 고정화 효소활성이 낮아지면 담체를 회수하여 효소를 고정화하여 재사용할 수 있기 때문에 담체의 가격이 높은 경우는 장점이 될 수 있다[1,14].

\section{충진층 반응기 연속공정}

충진층 효소 반응기에서 온도 $50^{\circ} \mathrm{C}$ 그리고 $\mathrm{pH}$ 9에서 연속 적으로 casein 용액을 공급하면서 유속을 $30 \mathrm{ml} / \mathrm{hr}$ 부터 110 $\mathrm{ml} / \mathrm{hr}$ 변화시키면서 부피 유속 변화에 대한 고정화된 효소의 활성을 96시간 연속 조업 후 측정하였다(Fig. 7). 유속이 낮을 수록 효소의 활성이 높음을 알 수 있는데 이것은 유속이 낮을 수록 충진층 반응기에서 체류시간이 증가함으로 효소활성이 높게 나타난다. 연속 운전에서 유속이 증가할수록 초기에 비 해 활성이 감소됨을 알 수 있다. 이것은 고정화 담체가 이온결 합으로 인한 약한 결합력으로 유속이 증가할수록 효소의 washout이 되기 때문으로 생각된다[24]. 연속 조업에서 부피 유속을 $30 \mathrm{ml} / \mathrm{hr}$ 로 하여 casein과 난황 단백질을 사용하여 원료에 대한 고정화 효소의 활성에 대한 영향을 조사하였다 (Fig. 8). 96 시간 후 casein을 사용했을 경우 고정화 효소의 활성이 초기 활성의 $83 \%$ 를 유지하였지만 난황 단백질의 경우 는 초기 활성의 $61 \%$ 를 유지하였다. 이것은 난황 단백질 원료 


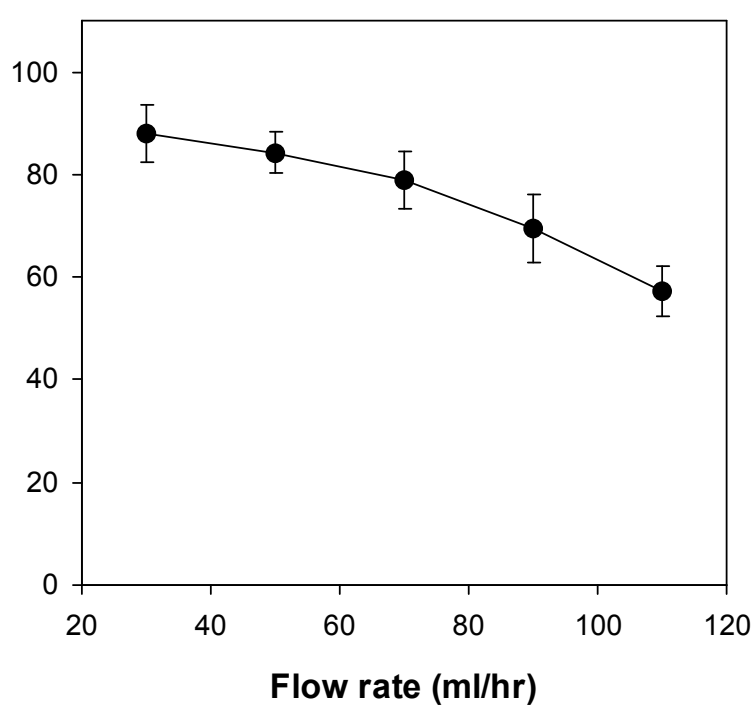

Fig. 7. Effect of flow rate on the activity of immobilized enzyme in continuous packed-bed reactor system.

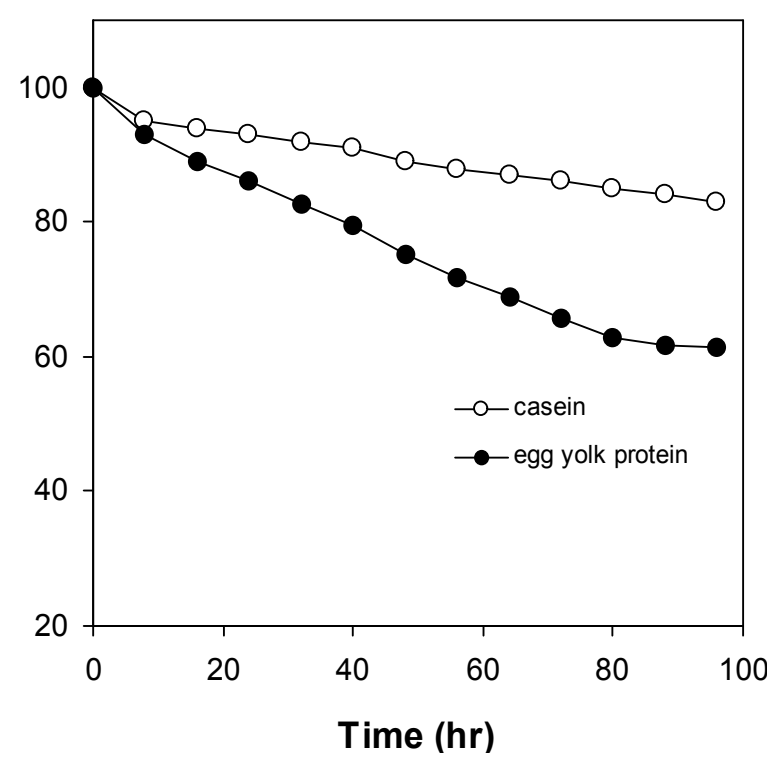

Fig. 8. Effect of raw materials in continuous packed-bed reactor system on the activity of the immobilized protease.

에는 여러 물질이 혼합되어 있기 때문에 연속 조업에서 고정 화 효소의 비 활성화를 촉진하는 것으로 판단된다[19].

\section{References}

1. Ahmed, S. A., S. A. Saleh, and A. F. Abdel-Fattah. 2007. Stabilization of Bacillus licheniformis ATCC 21415 alkaline protease by immobilization and modification. Aust. J. Basic Appl. Sci. 1, 313-322.

2. Altun, G. D. and S. A. Cetinus. 2007. Immobilization of pepsin on chitosan beads. Food Chem 100, 964-971.

3. Bayramoğlu, G., M. Yılmaz, A. Ü. Şenel, and M. Y. Arıca.
2008. Preparation of nanofibrous polymer grafted magnetic poly (GMA-MMA)-g-MAA beads for immobilization of trypsin via adsorption. Biochem Eng. J. 40, 262-274.

4. Benkhelifa, J., C. Bengoa, C. Larre, E. Guibal, Y. Popineau, and J. Legrand. 2005. Casein hydrolysis by immobilized enzymes in a torus reactor. Process Biochem 40, 461-467.

5. Cao, L. 2005. Immobilized enzymes: science or art. Curr. Opin. Chem Biol. 9, 217-226.

6. Gea, S., H. Bai, H. Yuan, and L. Zhang. 1996. Continuous production of high degree casein hydrolysates by immobilized proteases in column reactor. J. Biotechnol. 50, 161-170.

7. Greenberg, D. M. 1957. Plant proteolytic enzymes. Methods Enzymol. 2, 54-64.

8. Gutierrez, M. A., T. Mitsuya, H. Hatta, M. Koketsu, R. Kobayashi, L. R. Juneja, and M. Kim. 1998. Comparison of egg-yolk protein hydrolysate and soybean protein hydrolysate in terms of nitrogen utilization. Br. J. Nutr. 80, 477-484.

9. Haider, T. and Q. Husain. 2008. Concanavalin A layered calcium alginate-starch beads immobilized $\beta$-galactosidase as a therapeutic agent for lactose intolerant patients. Int. J. Pharm 359, 1-6.

10. Hong, J., P. Gong, D. Xu, L. Dong, and S. Yao. 2007. Stabilization of a-chymotrypsin by covalent immobilization on amine-functionalized superparamagnetic nanogel. $J$. Biotechnol. 128, 597-605.

11. Juneja, L. R., M. Koketsu, K. Nishimoto, M. Kim, T. Yamamoto, and T. Itoh. 1991. Large-scale preparation of sialic acid from chalaza and egg-yolk membrane. Carbohydr. Res. 214, 179-183.

12. Lowry, O. H., N. J. Rosenbrough, A. L. Farr, and R. J. Randall. 1951. Protein measurement with the folin phenol reagent. J. Biol. Chem 193, 265-275.

13. Mannheim, A. and M. Cheryan. 1981. Continous hydrolysis of milk protein in a membrane reactor. J. Food Sci. 55, 381-385.

14. Mateo, C., J. M. Palomo, G. Fernandez-Lorente, J. M. Guisan, and R. Fernandez-Lafuente. 2007. Improvement of enzyme activity, stability and selectivity via immobilization techniques. Enzyme Microb. Technol. 40, 1451-1463.

15. Ortega, N., M. Perez-Mateos, M. C. Pilar, and M. D. Busto. 2009. Neutrase immobilization on alginate-glutaraldehyde beads by covalent attachment. J. Agric. Food Chem 57, 109-115.

16. Parkinson, T. L. 1966. The chemical composition of eggs. J. Sci. Food Agric. 17, 101-106.

17. Potumarthi, R., C. Subhakar, A. Pavani, and A. Jetty. 2008. Evaluation of various parameters of calcium-alginate immobilization method for enhanced alkaline protease production by Bacillus licheniformis NCIM-2042 using statistical methods. Bioresour. Technol. 99, 1776-1786.

18. Puhl, A. C., C. Giacomini, G. Irazoqui, F. Batista-Viera, A. Villarino, and H. Terenzi. 2009. Covalent immobilization of tobacco-etch-virus NIa protease: a useful tool for cleavage of the histidine tag of recombinant proteins. Biotechnol. Appl. Biochem 53, 165-174. 
19. Roy, I. and M. N. Gupta. 2003. Lactose hydrolysis by Lactozym immobilized on cellulose beads in batch and fluidized bed modes. Process Biochem 39, 325-332.

20. Sharma, S., A. Mittal, V. K. Gupta, and H. Singh. 2007. Improved stabilization of microencapsulated Cathepsin B in harsh conditions. Enzyme Microb. Technol. 40, 337-342.

21. Silva, C., G. Gubitz, and A. Cavaco-Paulo. 2006. Optimization of a serine protease coupling to Eudragit S-100 by experimental design techniques. J. Chem Technol. Biotechnol. 81, 8-16.

22. Silva, C., Q. Zhang, J. Shen, and A. Cavaco-Paulo. 2006.
Immobilization of proteases with a water soluble/insoluble reversible polymer for treatment of wool. Enzyme Microb. Technol. 39, 634-640.

23. Wang, S., H. Bao, P. Yang, and G. Chen. 2008. Immobilization of trypsin in polyaniline-coated nano-Fe3O4 /carbon nanotube composite for protein digestion. Anal. Chim Acta 612, 182-189.

24. Yu, X., Y. Li, C. Wang, and D. Wu. 2004. Immobilization of Aspergillus niger tannase by microencapsulation and its kinetic characteristic. Biotechnol. Appl. Biochem 40, 151-155.

\section{초록 : 충진층 반응기에서 고정화 효소에 의한 난황 단백질의 가수분해}

\section{강 병 철*}

(동의대학교 화학공학과)

난황단백질 가수분해를 위한 알칼리성 단백질분해효소를 5가지 담체 Duolite A568, Celite R640, Dowex-1, Dowex 50W 그리고 Silica gel R60 에 고정화하였다. Duolite A568의 경우에 24.7\%의 최대 고정화 효율을 나타내었 다. 자유 효소와 고정화 효소에 대한 최적의 $\mathrm{pH}$ 는 각각 8 과 9 였고, 최적의 $\mathrm{pH}$ 는 고정화에 의해 염기성으로 1 만큼 증가하였다. 그러나 최적 온도는 자유 효소와 고정화 효소 모두 $50^{\circ} \mathrm{C}$ 로 같았다. 고정화 효소가 자유 효소에 비해 높은 열 안정성을 보였다. 재사용 회분식 공정에서 $10 \mathrm{cycle}$ 동안 효소활성은 초기 활성의 $86 \%$ 를 유지하였다. 연속 공정을 위한 충진층 반응기에서 여러 유속에 대한 장기 조업에서 효소 활성의 안정성 평가하였는데 낮은 유속일수록 높은 활성을 유지하였다. 연속 조업에서 casein과 난황 단백질을 사용하여 원료에 대한 고정화 효소의 활성에 대한 영향을 조사하였다. 96 시간 연속 조업에서 casein의 경우는 초기 활성의 $83 \%$ 를 유지하였고 난황 단백 질의 경우는 초기 활성의 $61 \%$ 를 유지하였다. 